\title{
Comments
}

\section{Comment on A Theory of the Consumer Product Warranty}

\author{
William C. Whitford $†$
}

Professor George Priest's recent article, $A$ Theory of the Consumer Product Warranty,' performs a valuable service by reminding us that consumers can sometimes reduce losses from defective products more cheaply than manufacturers. Where losses from product defects are essentially unavoidable, consumers may be the most efficient insurers of those losses. Professor Priest's comprehensive and technically proficient analysis of the implications of these points for the content of consumer product warranties is an important contribution to the literature.

Nonetheless, I believe that Professor Priest's article has serious analytic flaws. ${ }^{2}$ In addition, its policy suggestions are premised on a mistaken assumption about the law on an important point. ${ }^{3}$ Partly because of these mistakes, the article provides little support for its principal thesis, or for the implication derived from the thesis that complete judicial deference to the terms of consumer product warranties would reduce the losses from defective products. After briefly summarizing Professor Priest's article, I will detail and document these criticisms.

I. A Synopsis of the Article

An important objective of the article is to develop a positive theory of the content of consumer product warranties, that is, a theory that predicts

$\dagger$ Professor of Law, University of Wisconsin Law School. I owe much thanks for helpful suggestions by my many colleagues who read earlier drafts of this comment; William Clune, Robert Gordon, Neil Komesar, Judith Lachman, Stewart Macaulay, Gerald Thain, and David Trubek. Of course, I bear sole responsibility for the views expressed and for any errors.

1. 90 YALE L.J. 1297 (1981) [hereinafter cited by page number only].

2. The most serious problem of this nature is Professor Priest's failure to consider a wide number of competing explanations for the content of warranties. See infra pp. 1380-84 \& notes 32-44. Part of the analysis also seems premised on mistaken assumptions about the content of other relevant scholarship. Infra note 29.

3. Infra pp. 1384-85. 
warranty content. Professor Priest's "investment theory" predicts that warranties will contain the same terms that they would contain in a nearly perfect market. ${ }^{4}$ According to his investment theory, there are two principal determinants of warranty content in such a market.

First, if the losses from product defects are avoidable through appropriate actions, the warranty will allocate the loss to the party who can avoid it at least cost. ${ }^{5}$ Sometimes losses are best avoided through preventive investments - by the manufacturer through investments in product design or quality control, or by the consumer through investments in a search for the product best adapted to the intended use and investments in proper care and maintenance of the product after purchase. In other instances, losses are best avoided through the repair of a malfunctioning product, and either the manufacturer or the consumer can be the least-cost repairer. Whatever the cheapest method of loss avoidance, the investment theory predicts that warranty terms will allocate losses to induce efficient loss avoidance by the efficient loss avoider.

If losses from product defects are not totally avoidable, then the second determinant of warranty content under the investment theory is the effectiveness of the manufacturer as an insurer against losses. For example, if the risk of loss from product defects varies greatly among consumers, due to important differences in the circumstances of each consumer, Priest believes that the manufacturer is a relatively poor insurer because it usually cannot segregate consumers into risk classes as cheaply and effectively as alternative insurers. ${ }^{6}$ In these circumstances, the investment theory predicts that manufacturers will limit warranty coverage to those risks that virtually all consumers share, forcing consumers that face greater risks to self-insure or to obtain alternative insurance. Thus, low risk consumers will not pay for more insurance than their circumstances require. Warranties are likely to exclude consequential damages on this basis, for example, if the potential magnitude of consequential damages varies dramatically among consumers. ${ }^{7}$

Together with the investment theory, Professor Priest outlines two com-

4. Pp. 1307-13. Priest's hypothetical market exhibits perfect information and perfect competition, but deviates from the ideal of a completely perfect market by utilizing standardized contracts to minimize transaction costs.

5. Pp. 1308-09. For example, the investment theory suggests that refrigerator warranties exclude coverage for dislodged refrigerator shelves because consumers can repair dislodged shelves more cheaply than manufacturers, who would have to incur the cost of sending a repairperson to the consumer's home.

6. Pp. 1314-19. In considering economies of information acquisition, Professor Priest again deviates from the assumption of a perfect market and considers transaction costs. See supra note 4 . Consumers can often arrange for alternative insurance against losses from product defects through homeowners, medical and automobile insurance policies.

7. Pp. 1318, 1346. 
peting theories of warranty content. $\mathrm{He}$ attributes the "exploitation theory" to several scholars who have written on the problems posed by standard-form contracts, such as Friederich Kessler, Dean Prosser and Arthur Leff. According to Priest, the "exploitation theory predicts, in general, that manufacturers will limit their legal obligations to consumers as much as possible,"8 and that manufacturers have the power to limit their obligations because of their superior bargaining power. In Priest's opinion, the exploitation theory has induced the courts to impose liability on some manufacturers irrespective of exclusionary warranty terms. ${ }^{9}$

The third theory of warranty content that the article identifies is the "signal theory". This theory postulates that consumers regard the extent of warranty coverage as a "signal" of a product's reliability. If a product has no warranty coverage, consumers will believe that the manufacturer has little confidence in the product's quality. As a result, successful marketing of a product requires that the major terms of warranty meet industry norms. The aberrant warranties, if any, are likely to offer better than normal coverage, as a few manufacturers try to convince consumers that their products are of better than average quality. With respect to the less prominent terms of a warranty, however, signal theorists do not expect market pressures to affect warranty coverage, and manufacturers are likely to draft the less prominent terms so as to limit warranty coverage. In Professor Priest's words, "(a)t this point, the exploitation and signal theories converge."10

After describing the three theories, Professor Priest tests them by examining the content of sixty-two product warranties issued in 1974. He states that according to exploitation theory warranty coverage should decline as the manufacturer's market power increases. Priest finds that his data are inconsistent with that hypothesis. ${ }^{11}$ The data do indicate considerable uniformity within industries in some of the more prominent warranty terms, thus partly confirming the signal theory, but Professor Priest emphasizes that the signal theory is unable to explain other findings, such as the apparent lack of correlation between warranty duration and the service-life expectancy of warranted products. ${ }^{12}$

The longest section of the article specifically anlayzes six categories of warranty provisions. ${ }^{13}$ Within each category, Professor Priest concludes

8. P. 1301.

9. His principal illustration is the famous case of Henningsen v. Bloomfield Motors, 32 N.J. 358, 161 A.2d 69 (1960).

10. P. 1305.

11. Pp. $1320-25$.

12. Pp. 1326-27.

13. Pp. 1328-46. 
that his investment theory "more comprehensively"14 explains warranty content than the other two theories. This conclusion rests primarily on the considerable variation of warranty provisions within each category. The exploitation theory, in his view, can explain variation only in terms of the market power of manufacturers, but the data do not support that explanation. The signal theory predicts substantial uniformity in warranties, with variations limited to a few firms offering more extensive coverage than the norm. In each category, Professor Priest finds greater variation in warranty terms than the signal theory predicts. As to the investment theory, however, Professor Priest suggests possible differences among firms and products that affect whether the firm or its customers can most cheaply insure or avoid the risk of loss from product defects, and then illustrates how these differences might account for many of the observed variations in the six categories of warranty terms.

Professor Priest concludes that this analysis provides substantial evidence for his investment theory, although he liberally calls for further research. ${ }^{15} \mathrm{He}$ then proceeds to discuss the policy implications of the investment theory if established. ${ }^{16}$ That discussion focuses on various court decisions that expand manufacturer liability beyond the warranty contract, and especially on decisions that adopt strict products liability. According to Priest, the investment theory implies that such decisions "diminish . . product life and increase . . . the rate of product defects,"17 and have "a regressive redistributional effect."18 The clear implication of this discussion is that regulation of consumer product warranties is undesirable, and that courts should respect disclaimers and limitation of remedy clauses.

\section{Critique of the Article}

Professor Priest presents his investment theory as what I will call a complete theory of warranty content. That is, Priest hypothesizes that if one knew who is the least-cost risk avoider or the most effective insurer with respect to a particular product, one could accurately predict all of the terms of the product's warranty. ${ }^{19}$

14. Pp. 1347.

15. At one point Professor Priest characterizes the results of his survey of warranty content as "highly suggestive," presumably of the validity of his investment theory. P. 1320. At another point he states "that the investment theory explains warranty practices more comprehensively than either the exploitation or signal theory." P. 1347. Denials that the theory has been conclusively proved, and calls for further research and study, are made repeatedly throughout the article. See p. 1347.

16. Pp. 1347-51.

17. P. 1349.

18. P. 1351.

19. That Professor Priest posits his investment theory as a complete theory is clear in the passage where he first introduces the theory. P. 1307. 
Professor Priest might have advanced the investment theory as suggesting several but not all of the determinants of warranty content-what I will call a partial theory of warranty content. If he had done so, the theory would not be controversial. Few commentators would doubt that the considerations identified in Professor Priest's investment theory do and should influence warranty content. ${ }^{20}$ It is the suggestion that the investment theory is a complete theory of warranty content that makes Priest's position noteworthy and provocative.

The importance of this distinction between a complete theory and a partial theory is clear in Professor Priest's discussion of the implications of his position. He suggests that if the investment theory is correct, judicial

Priest does not argue that the investment theory is an accurate predictor of warranty content because the consumer product market is a perfectly operating market, save only a few accommodations for transaction costs. Rather, he apparently concedes that many consumers lack important information at the time of contracting. See pp. 1346-47. Thus, it appears to be his hypothesis that product warranty content in a less-than-perfect world is the same as it would be if the market operated perfectly.

The distinction between a market that operates perfectly and one that performs as if it were perfect is not important to an understanding of Professor Priest's discussion of the evidence supporting his investment theory. In either instance, the case for the investment theory as a complete theory rests on its ability to refute alternative theories of warranty content. The distinction becomes quite important, however, in assessing the policy implications that Professor Priest attributes to the investment theory. See infra p. 1384.

20. Thirteen years ago, in an article cited many times by Professor Priest, I identified several factors similar to those identified by the investment theory as justifying various conditions and limitations in the standard automobile warranty. Whitford, Law and the Consumer Transaction: A Case Study of the Automobile Warranty, 1968 WIS. L. REV. 1006, 1063-65. That Professor Priest considers his theory novel nonetheless is further indication that he intends it as a complete theory of warranty content.

Professor Priest may disagree that most commentators consider the investment theory uncontroversial as a partial theory of warranty content. At one point, Professor Priest identifies as "critical" to exploitation theory the presumption that "allocative investments by a consumer are empirically unimportani to the optimization of the productive life of the good." P. $1312 \mathrm{n} .89$. The principal commentator cited in support of this statement is the late Professor James. James, General Products-Should Manufacturers Be Liable Without Negligence? 24 TENN. L. REV. 923 (1951); James \& Dickinson, Accident Proneness and Accident Law, 63 HARV. L. REV. 769 (1950). In both of these articles, however, Professor James principally argues that the contributory negligence principle should not necessarily exculpate a defendant from tort liability because of the accident victim's moral fault. If the victim's accident is foreseeable and preventable by an appropriate investment by the defendant, James contends that the law should provide an incentive to make that investment even if the victim's blameworthy conduct is one cause of the accident. That Professor James was not oblivious to the need for investments by consumers is clear in the following passage:

While liability . . . would be strict, in the sense that negligence would no longer be required, yet this does not mean that the maker [of the product] would be held for all injuries caused by his products. Any product may become the instrumentality of serious injury or death-consider for instance the lethal possibilities that lie in a book placed strategically at the top of a long dark flight of strairs. In [strict liability] as well as negligence a plaintiff must trace his injury to a quality or condition of the product which was unreasonably dangerous either for a use to which the product would ordinarily be put, or for some special use which was brought to the attention of the defendant.

James, supra, at 923, 926-27 (emphasis in original). Concededly, there are passages in Professor James's articles that tend to support the quotation from Professor Priest at the beginning of the paragraph. In my opinion, Professor Priest has read those passages out of context. And even if I am wrong, I doubt that Professor Priest could find other "exploitation theorists" who doubt the validity of the investment theory as a partial theory of warranty content. 
decisions that expand a manufacturer's warranty liability beyond its contractual limits increase losses from product defects. ${ }^{21}$ If the investment theory is just a partial theory of warranty content, however, Priest should concede that judicial decisions that expand warranty liability might improve the efficiency of loss allocation in some instances. That is, such decisions might counteract the effects of warranty determinants other than those suggested by the investment theory. ${ }^{22}$ If Professor Priest's investment theory is correct as a complete theory of product warranty content, on the other hand, judicial review can only undermine the efficiency of the contractual scheme for minimizing product-defect losses because contractual terms are the same as they would be if negotiated under conditions of perfect information and competition. Thus, the question whether the investment theory is a complete or a partial theory is absolutely crucial to its policy implications.

Professor Priest's case for the investment theory as a complete theory of warranty content, or even as a predominant theory of warranty content, ${ }^{23}$ rests on three principal points. First, he argues that consumer preferences influence warranty content, even in the absence of bargaining. Second, he examines the content of the product warranties in his sample and argues that the content, and particularly the variance in the content among different warranties, is consistent with his investment theory. Third, he argues that his data tend to refute alternative theories of warranty content. I will now examine each of these arguments. It is my contention that Professor Priest's case for his investment theory as a complete or predominant explanation of warranty content rests entirely on his third argument, and that this argument is seriously deficient because it fails to consider many alternative theories of warranty content.

Consumer preferences and warranty content. Professor Priest identifies

21. P. 1349.

22. This statement presumes that courts, in deciding whether to expand warranty liability, give some weight to the considerations that the investment theory identifies. Judicial decisions are commonly based on considerations such as reasonableness and conscionability, which are sufficiently general to permit courts to weigh such considerations.

The judiciary, like the market, is an imperfect institution. Despite market failures, judicial involvement may be counterproductive if judicial imperfections are of greater consequence than market imperfections. See Komesar, In Search of a General Approach to Legal Analysis: A Comparative Institutional Alternative, 79 MiCH. L. REV. 1350 (1981).

23. Though Professor Priest presents his investment theory as a complete theory of warranty content, readers of the article may interpret the theory as one that more comprehensively explains the predominant influences on warranty content than do other theories. As a predominant theory of warranty content, the investment theory, even if validated, cannot establish that judicial decisions expanding warranty liability increase losses from product defects, but it may raise questions about the desirability of those decisions. The case for the investment theory as a predominant theory of warranty "content, however, is essentially the same as the case for a complete theory-that is, it depends on refutation of plausible alternative explanations of warranty content-and hence can be critiqued in the same manner. 
two ways in which consumer preferences can influence warranty content, while conceding that consumers usually lack knowledge of warranty content at the time of bargaining. ${ }^{24}$. Sellers who are financially dependent on repeat sales to customers will not want consumers to learn of limited warranty coverage when a defect appears. Moreover, manufacturers may compete for the patronage of a small group of consumers who are knowledgeable about warranty content and whose purchase decisions are influenced by that content. ${ }^{25}$ Although consumer preferences probably do influence warranty content to some extent for these reasons, this fact alone cannot establish the investment theory as a complete or predominant explanation of warranty content. It establishes only that consumer preferences are one factor, perhaps among many, that influence warranty content and that explain variations in warranty terms.

The consistency of warranty content and the investment theory. Professor Priest's illustrations of how various product warranty terms may reflect investment theory considerations are on the whole plausible. As Professor Priest sometimes recognizes, ${ }^{26}$ however, this part of his argument is very much in the realm of armchair theorizing. His information about the technologies of the products that he discusses, the risks presented by their use, and the kinds of insurance policies readily available to consumers appears no greater than that possessed by any reasonably intelligent lay observer. Without greater information of this nature, this prong of the argument cannot possibly establish that warranty terms allocate losses to the least-cost risk avoider and the most effective insurer. Therefore, it cannot possibly refute the existence of determinants of product warranty content that cause warranties to vary from the predictions of the investment theory.

For example, Professor Priest observes that two-thirds of the warranties in his sample require the consumer to bear the cost of transporting a defective good, perhaps over a considerable distance, to a manufacturer's service center. This provision may be consistent with the investment theory, he observes, because "[c]onsumers located more centrally may find it cheaper to bear . . . transport charges themselves than to purchase coverage for such charges in a warranty."27 Though plausible, it is also possible

24. Pp. 1346-47.

25. See generally Schwartz \& Wilde, Intervening in Markets on the Basis of Imperfect Information: A Legal and Economic Analysis, 127 U. PA. L. REV. 630 (1979).

26. Professor Priest states: "These explanations of the data . . . are only suppositions." P. 1346. The statement is apparently limited to his discussion of disclaimers of merchantability and exclusions of consequential damages.

27. P. 1342. In Professor Priest's terminology, this means that many consumers find it less costly to self-insure against this risk of loss from a product defect, as compared with having the manufacturer provide insurance through the warranty.

Professor Priest's explanation for variations in the inclusion of the transport charge provision is 
that transportation clauses induce manufacturers to forego the expense of decentralizing service centers or otherwise minimizing transport charges. This increases the consumer's cost and inconvenience of making warranty claims, thereby presumably reducing the number of claims put forward. If transport charge clauses are among the warranty terms less likely to be noticed by consumers at the time of contracting, manufacturers may include them precisely to reduce warranty costs in these ways without suffering adverse sales consequences. ${ }^{28}$ If so, some of the warranty claims deterred by the transport clauses probably concern product defects that manufacturers can repair more cheaply than consumers.

Refutation of alternative theories. It should now be clear that Professor Priest's case for his investment theory as a complete or predominant explanation of warranty content rests mainly on the third prong of his argument-refutation of alternative theories of warranty content. If Priest could refute all alternative theories that have intuitive plausibility, he would generate considerable evidence for the investment theory as a complete theory. But he considers only two alternatives-the exploitation theory and the signal theory.

What Professor Priest calls the exploitation theory predicts that warranty coverage will vary inversely with the market power of manufacturers. Professor Priest tests the theory by searching for a relationship between warranty coverage and the manufacturer's share of sales in the relevant market, or between warranty coverage and the degree of industry concentration in the market. The data he collects do not support the existence of either relationship. ${ }^{29}$

apparently that some products are sold nationwide, others more locally. For products sold nationwide there is likely to be greater variation among consumers in the cost of transporting a defective good to a service center, and consequently a substantial consumer preference for exclusion of average transport costs from the warranty. P. 1342. Professor Priest makes no effort to test this explanation empirically, perhaps because he lacks information as to which of the products in his sample are marketed nationwide.

28. This explanation for why transport clauses might vary from the investment theory is consistent with the signal theory. Variations among warranties in transport clauses may reflect in part a variation among manufacturers in the extent to which they rely on repeat sales. A manufacturer heavily dependent on repeat sales does not want to impress customers encountering product malfunctions with the impracticality of collecting on warranty coverage.

29. A disturbing aspect of Professor Priest's article is his attribution of exploitation theory in general, as well as at least one of the specific propositions he tests empirically, to a wide group of previous scholars. In fact, none of the legal scholars cited by him, nor any of which I am aware, have specifically suggested the propositions Professor Priest tests in refuting what he calls exploitation theory. By associating so many earlier scholars with exploitation theory, Professor Priest gives the impression, perhaps unintentionally, that in refuting alternatives to investment theory he has considered the main alternatives suggested in the literature. It is my principal contention in this comment, developed subsequently in the text, that he has not done so.

Professor Priest's first empirical test of the exploitation theory centers upon the proposition that "warranties less favorable to consumers are offered by the larger rather than the smaller firms within an industry." Professor Priest expressly attributes this view to "most" exploitation theorists, but without citation of any authority that propounds that view. P. 1320. In another place in the article, 
Professor Priest next considers signal theory. His data, as well as other published data, offer significant support for the principal hypothesis of signal theory - that the prominent terms of product warranties tend to converge to an industry norm. ${ }^{30}$ Professor Priest seems to discard signal theory nonetheless because it cannot explain other aspects of warranty content. In particular, he notes a considerable disparity between the duration of warranty coverage and the service-life expectancy of the products that he examines. If consumers regard warranty duration as a surrogate measure for product quality, as the signal theory presupposes, then such a disparity should not exist. ${ }^{31}$ This analysis only refutes signal theory as a complete theory of warranty content, however, and Professor Priest's own

Professor Priest states: "[i]t . . . would be consistent with the assumptions of the [exploitation] theory ... for the terms of coverage to be correlated with the degree of manufacturer market power." P. 1301. Here he cites two commentators, Friederich Kessler and Arthur Leff. See Kessler, Contracts of Adhesion-Some Thoughts About Freedom of Contract, 43 CoLUM. L. REV. 629 (1943); Leff, Contract as Thing, 19 AM. U. L. REV. 131 (1970).

In one very limited sense, Professor Priest's specification of the exploitation theory is "consistent" with the work of earlier scholars that Priest cites. Those commentators have not developed explicit theories of warranty content. Instead, the thrust of their scholarship has been to demonstrate that standard form contracts involving consumers are not usually executed under perfect market conditions. They argue that because consumers often lack information about the content of contracts, one cannot be certain that the contracts are fair and efficient. Sometimes they assert that contracts are one-sided and unfair, without attention to the actual determinants of warranty content. Most any theory of warranty content, including one that associates warranty coverage with manufacturer market power, is potentially consistent with these propositions.

Certainly, however, in citing the work of Professors Kessler and Leff, Professor Priest can claim no direct support for the proposition that warranty coverage within an industry relates inversely to the size of the manufacturer. Professor Kessler comes closest to suggesting this proposition when he speaks of standard form contracts being "typically used" by enterprises with "strong bargaining power" and discusses the inability of the weaker party to shop for better terms "because the author of the standard contract has a monopoly . . . or because all competitors use the same clauses." Kessler, supra, at 632. But this language does not directly state that the content of standard contracts correlates with manufacturer size, and in my judgment, it suggests at least as clearly that warranty content is associated with market imperfections on the buyer side, rather than with the imperfections on the seller side that are the focus of Professor Priest's version of the exploitation hypothesis. See also infra p. 1380.

Nor can Professor Priest's first specification of the expolitation hypothesis be attributed to Professor Leff, as is clear from the following passage:

What the specific circumstances creating ... [manufacturer] power to impose terms [in an adhesion contract], whether sanctioned monopoly, lawful or unlawful oligopoly, lack of mobility and information, lack of interest [because each deal was too trivial to think about, or the imposed terms covered contingencies too hypothetical to engage attention] or what else will not concern us here.

Leff, supra, at 141 (emphasis added).

Professor Priest's other specification of the exploitation hypothesis is that warranty content is inversely related to the degree of concentration in the industry. P. 1323. Again he cites no commentator propounding this view, nor do I know of any. Later in this article, I suggest a reason why industry concentration may correlate directly with extensive warranty coverage. See infra p. 1383. Admittedly, however, some courts express views similar to this specification of the exploitation hypotheses. See Henningsen v. Bloomfield Motors, 32 N.J. 358, 391, 161 A.2d 69, 87 (1960).

30. Pp. 1320, 1339; see also Gerner \& Bryant, Appliance Warranties as a Market Signal, $15 \mathrm{~J}$. CONSUMER AFF. 75 (1981).

31. P. 1327. There are other aspects of warranty content that Professor Priest also finds signal theory inadequate to explain. See pp. 1329, 1339. 
data offer impressive support for signal theory as a partial theory of warranty content. Moreover, because signal theory posits a determinant of warranty content that seems likely to cause warranty content to differ from the predictions of the investment theory, Priest's inability to refute the signal theory as a partial theory of warranty content undercuts his most persuasive argument for the investment theory as a complete theory.

Theories of warranty content neglected by Priest. Perhaps the most serious flaw in Professor Priest's article is its failure to consider other partial theories of warranty content. There are many such theories that seem to explain aspects of warranty content as plausibly as the investment theory. I will identify and briefly discuss four alternative partial theories of warranty content that Priest failed to consider. The existence of such theories rebuts the principal argument that Priest makes for the investment theory as a complete or predominant theory of warranty content.

The first alternative theory of warranty content-one frequently suggested in the literature-emphasizes market imperfections on the buyer side, such as consumer ignorance and lack of sophistication, in contrast to the market imperfections on the seller side that Professor Priest associates with exploitation theory. ${ }^{32}$ The signal theory is one possible version of this position; its assumption that consumers associate warranty content with product quality presumes less than perfect information on the buyer side. Another version, not considered by Professor Priest, is the hypothesis that warranty coverage is less extensive for products that are sold primarily to consumers with little education, little experience in buying products of that type, and few practical choices available in the marketplace (most importantly, the poor). This hypothesis takes the much-discussed argument that the poor pay more than the middle class for similar products ${ }^{33}$ and extends that principle to warranty coverage.

To test this hypothesis, one should examine the performance of war-

32. Indeed, many of the commentators that Professor Priest considers exploitation theorists emphasize consumer ignorance and lack of information as important determinants of warranty content. See, eg., Llewellyn, Book Review, 52 HaRV. L. REV. 700 (1939); Kessler, supra note 29; Leff, supra note 29. In a footnote, Professor Priest acknowledges that many exploitation theorists presume some degree of consumer ignorance. P. 1303 n.40. For unexplained reasons, Professor Priest states that this assumption is "important, but not central" to these theorists. Id.

33. See D. CAPLOVTTZ, THE POOR PAY MORE (1967). Much of the difference between the poor and the middle class in the prices that they pay can be attributed to the extra costs of supplying goods at retail, and often on credit, in poor neighborhoods. See FEDERAL TRADE COMMISSION, ECONOMIC REPORT ON INSTALLMENT CREDIT AND RETAIL SALES IN THE DISTRICT OF COLUMBIA (1969).

Professor Priest suggests reasons why the poor may prefer less warranty coverage than wealthier consumers. Because of their lower incomes and less valuable assets, poor consumers on the average incur smaller losses from product defects than other consumers. The cost of warranty coverage does not vary with the income class of the buyer, however, and hence poorer consumers may prefer products with less extensive warranty coverage. P. 1351. For this reason, a differential in warranty coverage for products marketed to different classes of consumers, if established, could be consistent with the investment theory. 
ranty contracts as well as their content. ${ }^{34}$ The same consumer characteristics that may result in lower warranty coverage may also result in lesser ability to secure performance of warranty promises once a product defect becomes apparent. Consequently, for products sold primarily to the poor, manufacturers may promise more than they intend to perform. Even if warranty content does not vary according to the class of buyers, therefore, the hypothesis that the poor receive less warranty coverage cannot be refuted without attention to both warranty-in-the-books and warranty-inaction.

A second partial theory of warranty content emphasizes the organizational structure of the manufacturer. At the time that the warranties examined by Professor Priest were drafted, it made little difference to a manufacturer's legal position whether the warranty excluded liability for personal injury from a product defect. As Professor Priest acknowledges, such a clause would have no effect on the manufacturer's liability in tort, and probably would not limit damages for personal injury on a warranty theory as well..$^{35}$ The question arises, therefore, why clauses excluding such liability were included in warranties, given that their presence might have had a negative impact on sales to consumers who were ignorant of the law. Though there are several possible explanations, ${ }^{36}$ I suspect that the variation among firms in exclusions of personal injury liability are attributable in significant part to such factors as the role of the legal department in the firm, and the personal relationships between house counsel or other lawyers and the head of the sales department (which often has primary organizational responsibility for determining warranty content). ${ }^{37}$

34. Priest acknowledges the importance of information about warranty performance to the formulation of a theory of warranty content. P. 1320.

35. P. 1308 n.77. See U.C.C. § 2-719(3) (1978) .

36. Exclusion of liability for personal injury is often part of a more general warranty clause excluding all liability for "consequential damages." A general exclusion clause can have practical consequences. It may effectively foreclose a purchaser from seeking rescission of the sales contract and return of the purchase price as a remedy for breach of warranty. Under existing law, it is also potentially effective to exclude manufacturer liability for consequential property damage resulting from a product defect, such as the loss of property contained in a motor vehicle involved in a product-caused accident. The legal tradition of using a single contract clause to exclude these potential liabilities as well as liability for personal injury may account for many exclusions of the latter liability.

37. The investment theory accounts for variations in the exclusion of consequential damages on the ground that the range of injuries suffered by the users of some defective products (those sold with exclusion clauses) are greater than the range of injuries suffered by the users of other defective products (those without exclusion clauses). Professor Priest predicts that enough consumers of the first type of product will prefer self-insurance for injuries from product defects to insurance through the warranty to induce manufacturers to exclude consequential damages. Pp. 1343-46. There is some plausibility to this explanation, but the one in the text seems a priori equally plausible. Furthermore, Professor Priest's finding that all dryer warranties in his sample excluded consequential damages while none of the range warranties contained such an exclusion tends to refute the investment theory explanation. Although his sample included only two dryer warranties, and therefore may not be reliable, it seems implausible that there is a greater range in the extent of injuries suffered by users of defective dryers than in the extent of injuries suffered by users of defective ranges. 
The exclusion of personal injury liability has the earmark of a lawyer's afterthought-it is unlikely to make much difference but it cannot hurt. The inclusion of such clauses, therefore, may be as much a function of how much a lawyer participated in the drafting of the warranty as anything else. ${ }^{38}$ Many factors may account for the degree of lawyer participation in warranty drafting. Some may be consistent with the investment theory, but others seem at variance. For example, whether the chief executive officer or other high management official has legal training or is close socially to the firm's lawyer may have an important effect on lawyer participation.

A third partial theory suggests the fear of government regulation as a determinant of warranty content. It seems highly plausible that corporate managers decide not to restrict warranty coverage as extensively as marketplace conditions might permit, for fear that such behavior might stimulate legislative and judicial regulation of warranty content. ${ }^{39}$ It is surprising that Professor Priest did not mention this possibility, because his warranty sample was drawn from 1974-the very year that Congress considered legislation that became the Magnuson-Moss Warranty Act. ${ }^{40}$ Fear of government regulation as a determinant of warranty content can be consistent with the variations in warranty content that Priest observes if one supposes that corporate managers differ in the extent to which they fear government regulation. Government regulation is often thought most appropriate in concentrated industries and managers in those industries may be particularly fearful that their warranty practices will come under legislative scrutiny. Ironically, this argument suggests that warranties in concentrated industries will offer greater coverage than warranties in more competitive industries, precisely the opposite of one of Professor

38. A related factor may be the tendency in some industries for firms to copy the technical details of the warranties of another firm, perhaps because the latter firm is known to have cleared its warranty through a lawyer. Such a tendency may account for the uniformity that Professor Priest observes in the presence or absence of exclusion clauses within particular industries.

39. The effect of this fear, as well as other partial determinants of warranty content, could be to induce the drafting of warranty terms that are consistent with the investment theory. In the absence of direct evidence that warranty content is consistent with investment theory, however, the unrefuted possibility of these various partial determinants of warranty content is sufficient to rebut the principal evidence that Professor Priest has for the investment theory-refutation of alternative theories of warranty content. Morcover, even if the net effect of these different partial determinants on warranty content were consistent with the predictions of investment theory, the theory would not have the policy implications suggested by Professor Priest. Eliminating the possibility of warranty regulation might produce a substantial change in warranty content. See infra p. 1384.

40. 15 U.S.C. $\$ \S 2301-2312$ (1976). There has been little decline in the extent of warranty coverage since the Act. Note, An Empirical Study of the Magnuson-Moss Warranty Act, 31 STAN. L. REV. 1117,1140 (1979). The Act largely eschews substantive regulation of warranty content, but manufacturers may fear that restriction of warranty coverage would induce Congress to reconsider its decision to refrain from substantive regulation. Indeed, for a period preceding the adoption of the MagnusonMoss Warranty Act, Congress seriously considered a proposal to subject automobile warranties to special substantive regulation. See Whitford, supra note 20, at 1072-75. 
Priest's versions of the exploitation hypothesis. ${ }^{41}$

A fourth alternative theory of warranty content arises from the admittedly controversial proposition that consumers tend to overdiscount long term risks (such as the consequences of product defects) in favor of short term gratification (such as a lower purchase price)..$^{42}$ This propensity may result from psychological factors or from systematic lack of information, experience and sophistication. If this proposition is correct, it implies that consumers prefer less extensive warranty coverage than the investment theory predicts. If consumer preferences influence warranty content, as Priest argues, then the investment theory would be inadequate as a complete predictor of warranty content.

All of these alternative theories of warranty content are partial theories. They suggest a complete theory of warranty content that posits many determinants of content, including the least-cost risk avoider and most-effective insurer considerations described by Professor Priest. Each determinant would have a somewhat different degree of influence. Professor Priest might object to such a theory on the ground that it is so complicated and unspecified as to be empirically unverifiable. ${ }^{43} \mathrm{I}$ might answer that, with enough inclination, time and money, I could construct a more specific and verifiable complete theory of warranty content through the use of regression equations and similar social science techniques. A more fitting answer is that this complete theory is no less verifiable than Professor Priest's investment theory. The investment theory cannot be validated on the ground that consumer product warranty contracts are concluded in perfect markets, or on the ground that all alternative theories of warranty

41. Still another reason to anticipate more extensive warranties in concentrated industries stems from the theories of some economists about the nature of competition in such industries. Firms in concentrated industries may try to create barriers to entry that foreclose new entrants and protect the firms' ability to realize monopoly profits. See generally J. BAIN, BARRIERS TO COMPETITION (1956); J. BAIN, INDUSTRIAL ORGANIZATION (1959). A new entrant probably requires more capital when the new product must be sold with an extensive warranty. If the signal theory is correct in predicting that firms offering less warranty protection than the industry norm give consumers the impression that their goods are of lesser quality, then the firms in a concentrated industry could create barriers to entry by establishing extensive warranty protection as the norm. Professor Priest was unable to find any relation between industry concentration and warranty content on the basis of his data, but as he would readily concede that data was limited and the question cannot be regarded as settled.

42. I have discussed this point more extensively elsewhere. Whitford, $A$ Critique of the Consumer Credit Collection System, 1979 WIS. L. REV. 1047, 1074. Professor Priest notes the hypothesis that consumers may systematically overdiscount long-term risk in a footnote to his article, but he does not take account of it in developing his thesis, perhaps because he does not agree with it. P. 1335 n.152.

I recognize the difficulty in stating that consumers "overly" discount long term risk, for it presupposes an ability to determine an "appropriate" discount rate. I discuss this problem elsewhere. Whitford, supra, at 1074 n.95. For purposes of this comment, however, it is sufficient to posit that consumers discount long-term risk more than the least-cost risk avoider and most-effective insurer concerns of the investment theory would contemplate.

43. At one point Professor Priest identifies a partial theory of warranty content suggested by others but dismisses it because the critical determinant of warranty content could not be accurately measured. Consequently, the theory was not verifiable. P. 1319 n.108. 
can be refuted. The only remaining means of validation is to determine through detailed empirical inquiry whether existing warranty terms best implement the least-cost risk avoider and most effective insurer considerations underlying the investment theory. I have already adverted to the vast amounts of data necessary for this task..$^{44}$

Policy implications of the investment theory. Although Professor Priest is not clear on this point, he does not appear to contend that the investment theory identifies all the determinants of warranty content-he seems to argue only that warranty terms are consistent with the investment theory, whatever the actual determinants of warranty terms. If this is his argument, then alteration of any of the social conditions that underlie warranty decisionmaking risks changing a key determinant of warranty content. For example, Professor Priest suggests that the adoption of strict products liability has increased the rate of product defects. Yet it may be precisely because of strict liability that manufacturers do not uniformly exclude liability for consequential losses, permitting Professor Priest to observe variations in the presence of exclusion clauses that, if enforced, might further least-cost risk avoider and most-effective insurer concerns. Consequently, the abandonment of strict products liability might have the unfortunate effect of moving warranty terms away from this optimal state. ${ }^{45}$

Aside from this concern, however, it is clear that Professor Priest's analysis of the implications of the investment theory is premised on a mistaken conception of the nature of strict products liability. He states that "[c]rucial to the adoption of the strict liability standard is the empirical assumption that consumers can take no action to prevent personal injury loss, ${ }^{\prime \prime 46}$ a position quite at odds with the investment theory. The quoted statement clearly implies that strict products liability law imposes no duty of reasonable care on consumers. Yet strict products liability is not really absolute liability; it does not hold the manufacturer liable for all productconnected injuries. Instead, the plaintiff must show that the product was "defective," perhaps that as a result of the defects the product was "unreasonably dangerous," ${ }^{37}$ and that the defects "caused" the injury. It is

44. See supra p. 1377. I also disagree with Professor Priest's assertion that the determinants of warranty content under the investment theory are reasonably easy to measure. See p. 1352.

45. Strict products liability results in the non-enforcement of certain warranty terms-in particular, exclusion clauses-while the investment theory hypothesizes that all warranty terms should be enforced. Yet, because of imperfections in the market, repeal of strict products liability may lead to an excessive number of exclusion clauses in warranties. This conundrum is a consequence of the presumption that warranties generally promote an efficient loss allocation even in the absence of a perfect market.

46. P. 1350.

47. See RESTATEMENT (SECOND) OF TORTS $§ 402 A$ (1965). 
now accepted both in the case $\operatorname{law}^{48}$ and in the literature ${ }^{49}$ that these concepts incorporate many of the least-cost risk avoider and most-effective insurer concerns that underlie the investment theory. This point is an important one, for if Professor Priest's characterization of strict products liability were correct, strict liability would certainly be undesirable. In fact, however, under a legal regime of strict liability courts can accommodate the concerns that underlie the investment theory. ${ }^{50}$

\section{Conclusion}

The key points in Professor Priest's article are the apparent suggestion that the investment theory is a complete theory of warranty content and the claim that the evidence, though not conclusive, tends to support the investment theory. As a partial theory of warranty content, the investment theory is uncontroversial and lacks the implications that Professor Priest identifies. Analysis indicates that the case for the investment theory as a complete theory rests almost entirely on Professor Priest's ability to refute alternative theories of warranty content. But he considers only two such alternative theories. One of these alternatives, the exploitation theory, is really his own creation, although he attributes it to a large group of earlier commentators. The other alternative, the signal theory, is actually substantiated as a partial theory of warranty content. More importantly, there are many alternative theories that Professor Priest does not identify or discuss. As a result, the evidence in favor of the investment theory as a complete explanation of warranty content is weak indeed. Warranty content is almost surely the product of numerous forces, and by conventional theory, some of those forces most likely justify legal regulation of warranty content.

48. See Barker v. Lull Engineering Co., 143 Cal. Rptr. 335, 573 P.2d 443 (1978).

49. See Schwartz, Foreword: Understanding Products Liability, 67 CALIF. L. REV. 435 (1979); Whitford, Strict Products Liability and the Automobile Industry: Much Ado About Nothing, 1968 WIS. L. REV. 83.

50. Apart from his apparent misunderstanding of the state of the law, Professor Priest's focus on strict products liability in discussing the implications of his theory is also puzzling. The logic of his position suggests an objection to all liability that exceeds the scope of the warranty, whether based on negligence, see McPherson v. Buick Motor Co., 217 N.Y. 382, 111 N.E. 1050 (1916), or on modern strict products liability. 